\title{
Social Conflict in Community (Study On Agrarian Conflict in Lolak District, Bolaang District, Mongondow, North Sulawesi)
}

\author{
Ferdinand Kerebungu* \\ Sociology education study program \\ Faculty of Social Science \\ Universitas Negeri Manado \\ Tondano, Indonesia \\ ferdinankerebungu@unima.ac.id
}

\author{
Siti Fathimah \\ Sociology education study program \\ Faculty of Social Science \\ Universitas Negeri Manado \\ Tondano, Indonesia \\ sitifathimah@unima.ac.id
}

\author{
Theodorus Pangalila \\ Pancasila and Civic Education \\ Department \\ Faculty of Social Science \\ Universitas Negeri Manado \\ Tondano, Indonesia \\ theopangalila@unima.ac.id
}

\begin{abstract}
Social conflict is a social phenomenon that is often observed in life together, and the causes of its occurrence can be caused by various problems that are happening in society. Many people do not want this condition, but because of the situations and conditions that exist in a society that cause social conflict, and the conflict is increasingly worrisome if it leads to destructive conflict. For this reason, the problems in research can be formulated as follows; "Why is there an agrarian conflict in Lolak District?" The purpose of this study is to describe the factors causing agrarian conflict between the community and PT. Anugerah Sulawesi Indah (PT ASI) in Lolak District, Bolaang Mongondow Regency. The method used in this study with data collection techniques through the process of observation and interviews. Based on the discussion of the research results, it can be stated several results which are the findings in this study, namely: 1) Conflict occurs due to differences in perspectives between farmers and HGU land cultivators, namely PT ASI, 2) The openness of the government as the facilitator with the farming community, 3) in In the event of peasant community resistance, the Bolaang Mongondow district government was unable to provide a solution that was acceptable to both parties. It can be concluded that the agrarian conflict in Lolak District was caused because between the Farmers, PT ASI, and the Regional Government, there was no agreement on the issue of land acquisition and utilization.
\end{abstract}

Keywords: Agrarian Conflict, Vertical Conflict, and Conflict Solutions

\section{INTRODUCTION}

Entering 2 decades after the New Order, it seems that the democratization process has not proceeded according to reform expectations. One of the phenomena that need our attention is that there are still contradictions in social life, such conditions could be due to the imperfect process of community empowerment (strengthening of civil society) so that the democratization process does not run correctly. The incomplete democratization process can be seen from the fact that there are still conflicts in society, both horizontal and vertical conflicts, as in reference [1], review regarding the resistance of the Lindu indigenous people in the Palu-3 hydropower development plan and the Central Sulawesi provincial government. The community resistance was triggered by the lack of socialization from the government regarding the construction of the Palu-3 hydropower plant.

Many other writings have examined conflict, such as reference [2], who looked at the US-China currency relationship to test three competing currencies regarding the influence of foreign economic threats on public opinion. In his writing, he saw how economic pressures were forced by foreign countries to follow the economic flow following foreign policies (US). This study provides new insights into policy issues regarding the effectiveness of economic coercion as a foreign policy strategy. Economic policy is not driven solely by mass public opinion, especially in authoritarian regimes like China. On the other hand, policymakers tend not to ignore public opinion completely. To the extent that leaders are concerned with public opinion, economic coercion tends to make it less than more likely that the government will change policy. Indeed, the Chinese leadership itself repeatedly claims that the response of its citizens to foreign pressure makes it more difficult for them to appreciate exchange rates [3].

This is different from reference [4], who review when and how collective action can increase conflict between groups. Likewise, with reference [5], who sees conflict resolution through amnesty, according to him, amnesty can be part of a compromise that can help resolve conflicts. Besides, Nugroho Trisnu Brata (2010) explains how social conflict and social integration occur in communities around the gold mine of PT. Freeport Indonesia. Various social conflicts that occur alternately with social integration are phenomena that often occur in communities. The cause is a conflict of interest in controlling natural resources. Likewise, with reference [6] but he saw how vulnerable conflicts occur in the world of work. In his review, he wrote about the causes of conflicts that often occur, including lack of clarity of expectations or guidelines, poor communication, lack of clarity on the jurisdiction, personality differences, conflicts of interest, and changes in organizations. When people work as a group, conflict is one of the most predictable outcomes [7].

Conflicts occur because of the coercion of the will by the dominant party (government or capital owners) without paying attention to the interests of the 
marginalized party (society), and even sacrificing it often occurs. As the object of this research is the coercion of the will and the absence of transparency by the Bolaang Mongondow Regency government towards the peasants of Lolak Village, Lolak District. This conflict occurred because of differences in interests between the government and farmers, and the government emphasized more on investment without paying attention to the interests of farmers, where the government granted HGU to PT Anugerah Sulawesi Indah (PT ASI). The HGU land provided by the Bolaang Mongondow Regency Government is agricultural land managed by the people of Lolak Village where there are coconut plants that are still productive (indeed the position of the land is an onderming land, a legacy from the Dutch East Indies government) which is a source of income and life for the farming community as stated earlier that the process of handing over the land from the Government to PT ASI did not begin with a socialization process or the government was not transparent in this matter. The lack of transparency between the government and the community is what triggers the conflict between farmers and PT ASI (including the government).

The conflict that occurred between PT ASI and the community was a dispute over the former HGU concession of PT Mongondow Indah (PT MI) which was managed by residents as agricultural land which had received a unilateral status transfer issued by the Bolaang Mongondow Regency government to become oil palm land from PT ASI. After PT MI ceased to function the land, the community in Lolak village was given the freedom to cultivate 762 ha of ex-HGU land by PT. The MI becomes agricultural land. The former PT MI HGU land was transferred unilaterally by the government to PT. ASI, by issuing a Business Use Rights (HGU) certificate, PT ASI for oil palm plantations, is a source of conflict. In the view of society, the government should prioritize the community over a company, in the sense that the government should prioritize the fulfillment of community needs. Responding to this conflict cannot be separated from the government's thinking that is more development-oriented. Cahyono stated that "a developmentalism perspective still dominates the character of our agrarian policy. The main marker can be seen from the expansion and deepening of extractive and exploitative industries of agrarian sources' (Tempo.com; 25 February 2019).

As a result of the unilateral transfer of land, there was a conflict between the community in Lolak village and the company. The community took action by evicting company employees who started cutting down coconut trees, which would be replaced with oil palm trees. Not only that, but community actions have also even led to anarchist acts such as burning guard posts and company boards. Besides, the community also protested by carrying banners that read "refuse to enter companies in Lolak District."

The core problem of the conflict between PT ASI and the community in Lolak District is the process of granting permission by the government to PT.ASI in Lolak District without prioritizing deliberation. Responding to the existing problems, according to reference [8], that "public trust is an important and essential thing in building an effective communication relationship between the community and between the community and the government and the private sector". Besides that the hope of finding a conflict resolution is also very instrumental in finding common ground between the two warring parties, it is rather intuitive that public involvement in efforts to promote peace will depend on people's desire for peace and their assessment of its possibilities [9].

Based on the description in the introduction, the problem in this study is: "why does the agrarian conflict between PT ASI and the community occur?". The purpose of this study is to describe and analyze the factors underlying the conflict between the people in Lolak District and PT ASI.

\section{RESEARCH METHOD}

The research method used is a qualitative research method using a case study approach (case study). According to Maxfield in reference [10], A case study, or case study, is a study of the status of a research subject who is pleased with a specific or distinctive phase of the whole personality. Data collection techniques are direct observation and interviews.

\section{RESULTS AND DISCUSSION}

Based on data from the Central Statistics Agency of Bolaang Mongondow Regency in 2018, the number of farmers in Lolak District was 3425 families out of a total population of 24,018 people who cultivated $762 \mathrm{Ha}$ of land. Based on these data, it shows that the majority of the population in Lolak District are farmers. It is not surprising that the people in Lolak Subdistrict are so enthusiastic about defending their cultivated land from the efforts of other parties to change land functions.

Based on the data obtained, the conflict that occurred was a community effort to defend their cultivated land in order to meet their daily needs, when viewed from the characteristics of the community, most of whom are farmers who have long cultivated the HGU land that PT MI left for $762 \mathrm{Ha}$. The people in Lolak District are generally farmers, so that their economic efforts depend on agriculture. The results of farming carried out by the community can be used to meet their economic needs as well as a source of funding for their children's education. That is why the farming communities in Lolak Sub district (especially four villages), continue to strive to maintain their cultivated land from PT ASI's efforts to divert land functions from horticultural crops to oil palm, which do not contribute to the income of the farming community.

The source of the conflict that occurred between the farming community and PT ASI in Lolak District was based on the farmers' disapproval of the Bolaang Mongondow Regency government's decision to grant a business license to PT ASI. The district government grants the company permission because the government is development-oriented or what Cahyono mentioned is a develomentalistic character or focuses on development 
programs (achievement of the APBD). In principle, the government's efforts are not wrong but do not harm the small community (farmers).

This is as in the review of reference [11], which explains how the limitedness and abundance of natural resources are some of the triggers for natural resource conflicts. In his review, he also cites how rich the island of Java is in teak forests, one of the highest quality forest products and because of its scarcity, it becomes an expensive commodity. The way the government manages product forests causes several problems. Under the guise of forest product sharing, farmers have the right to cultivate the land under the teak trees, but teak products remain the property of their rulers and their allies. As a result, farmers in the forest remain poor even though they live in forest areas.

Likewise, with the Lolak Community, the granting of permits to PT ASI is an effort of the local government to support the achievement of the national program, again what is being considered is the welfare of the small community. One of the central government's programs is to slowly replace fossil fuels to fuels sourced from palm oil (ethanol). With this in mind, the Bolaang Mongondow Regency government gave a business license to expand Indonesia's palm oil production. The occurrence of conflict between the community and the company was not only due to the inadequate socialization of the community but also because the company did not keep its promises made to the government, namely the profit-sharing agreement.

One of the requirements in obtaining a business license for every investor to invest is that there must be an EIA study. Although the EIA business from PT ASI has been issued, it has not been through a thorough study; one of the studies that have not been paid attention is the socio-economic and environmental health studies. In the Amdal study submitted by the company, it is limited to a study of toxic substances and a study of the carrying capacity of the land for production. So based on these facts, the Amdal study submitted by the company is only a reference that the document requirements for the operation of company activities have been fulfilled, and this issue is the reason why the community refuses to operate PT ASI. At the same time, the local government does not fully side with the community, from the explanation above, is a trigger factor for conflict.

The impacts that will arise from the conflict between the community and PT ASI are:

a. There will be conflicts on a large scale between the community who try to defend the land they cultivate if the company's HGU is going to be active in planting oil palm, this condition should be a significant concern for the local government of Bolaang Mongondow Regency.

b. If the local government does not solve this problem as soon as possible, it will disturb the harmonious relationship between the farming community and the government, because the community can no longer trust the government that does not keep its promises. c. If PT. ASI continues to plant oil palm in the disputed land, so the farming community in Lolak district will fight back because the farmers who cultivate the HGU land are the main source of livelihood for their families.

There is a reaction from the community in Lolak Sub district as stated earlier as a result of the lack of outreach from the government and companies to the community regarding the management of opening oil palm plantations, most of which are agricultural land managed by the community as the main source of livelihood for family farmers. Another factor that has become a source of conflict between the community in Lolak sub-district and PT ASI and the local government is the absence of transparency about the policies to be implemented in the process.

The local government of Bolaang Mongondow Regency should be in the process of granting PT ASI a permit, before granting the permit, it must carry out the socialization process to the affected community, which must be clear and transparent regarding the company's rights and obligations to the community related to corporate social responsibility (CSR), namely what the community will get from the problem of losing a source of income to support his family. For that, in the process of making policies such as granting a business license to a company must go through a steady procedure. In addition, the company must explain the impact of oil palm cultivation, both positive and negative. In this context, the community is marginalized by the government, and the government is not protecting the community by providing social protection so that it does not cause social conflict as a result of the marginalization process. So the community continues to protest to the local government and block company activities.

\section{CONCLUSION}

Based on the discussion of the research results that have been stated above, it can be concluded that; The occurrence of social conflicts in the agrarian sector between the farming community in Lolak District with the Regional Government and PT ASI was caused by the lack of transparency by the Government and PT ASI to the Farming Community because the socialization carried out did not involve farmers. There was no clarity about the use of the HGU and profit-sharing system between farmers and PT ASI.

\section{ACKNOWLEDGMENT}

Our gratitude goes to the Dean of the Faculty of Social Sciences, Manado State University who has provided support in writing this article. We also do not forget to thank all members of the community in Lolak Subdistrict, Bolaang Mongondow Regency, North Sulawesi who have been willing to participate in this research

\section{REFERENCES}

[1] F. Kerebungu and S. Fathimah, 'Pembangunan PLTA Palu-3 (Kajian Sosiologis-Antropologis atas Gagalnya Pembangunan PLTA Palu-3 di 
Kabupaten Donggala Sulawesi Tengah)', Indones. J. Sociol. Educ. Dev., vol. 2, no. 1, pp. 19-25, 2020.

[2] D. Gueorguiev, D. McDowell, and D. A. Steinberg, 'The Impact of Economic Coercion on Public Opinion: The Case of US-China Currency Relations', J. Conflict Resolut., p. $0022002720912323,2020$.

[3] R. Foot and A. Walter, China, the United States, and global order. Cambridge University Press, 2010.

[4] H. P. Selvanathan and B. Leidner, 'Modes of Ingroup Identification and Notions of Justice Provide Distinct Pathways to Normative and Nonnormative Collective Action in the IsraeliPalestinian Conflict', J. Conflict Resolut., p. $0022002720907660,2020$.

[5] L.-A. Daniels, 'How and when amnesty during conflict affects conflict termination', J. Conflict Resolut., p. 0022002720909884, 2020.

[6] A. R. Overton and A. C. Lowry, 'Conflict management: difficult conversations with difficult people', Clin. Colon Rectal Surg., vol. 26, no. 4, p. 259, 2013.
[7] O. Madalina, 'Conflict management, a new challenge', Procedia Econ. Financ., vol. 39, pp. 807-814, 2016.

[8] I. N. Sumaryadi, A. B. G. B. Indraatmaja, and N. E. Hutabarat, Sosiologi pemerintahan: dari perspektif pelayanan, pemberdayaan, interaksi, dan sistem kepemimpinan pemerintahan Indonesia. Jakarta: Ghalia Indonesia, 2010.

[9] O. A. Leshem and E. Halperin, 'Hoping for Peace during Protracted Conflict: Citizens' Hope Is Based on Inaccurate Appraisals of Their Adversary's Hope for Peace', J. Conflict Resolut., p. 0022002719896406, 2020.

[10] M. Nazir, 'Metode Penelitian. 2005', Jakarta Cetakan Pertama. Penerbit Ghalia Indones. Jakarta.

[11] H. Herdiansyah, B. S. Soepandji, F. S. S. E. Seda, and O. Dewi, 'Conflict Management of Renewable Natural Resources in the Border of Indonesia-Malaysia: Sustainable Environmental Approach', Procedia Environ. Sci., vol. 20, pp. 444-450, 2014. 